\title{
DESKRIPSI SIKAP SISWA: ADOPSI SIKAP ILMIAH, KETERTARIKAN MEMPERBANYAK WAKTU BELAJAR FISIKA DAN KETERTARIKAN BERKARIR DI BIDANG FISIKA
}

\author{
Dodi Setiawan Putra ${ }^{1 *}$, Artha Lumbantoruan ${ }^{1}$ dan, Sofia Christine Samosir ${ }^{1}$ \\ Jurusan Pendidikan Fisika \\ Fakultas Keguruan dan Ilmu Pendidikan \\ Universitas Jambi, Indonesia \\ *E-mail: dodisetiawan158@,gmail.com
}

\begin{abstract}
Website: https://jurnal.uin-antasari.ac.id/index.php/jtjik/index
Received: 8 November 2019; Accepted: 4 Desember 2019; Published: 13 Desember 2019
\end{abstract}

\begin{abstract}
This study aims to determine students' attitudes towards physics through indicators of scientific attitudes adoption, interest in increasing time to study physics and career interests in physics at SMA Ferdy Ferry Putra Kota Jambi. This type of research is survey research with the instrument used is a questionnaire. Research subjects were 125 students. Quantitative data analysis techniques using descriptive statistics. The results is from indicators of scientific attitudes adoption with a good category. Indicators of interest in increasing the time to study physics and career interest in physics category are sufficient respectively. Based on these results, students at SMA Ferdy Ferry Putra Kota Jambi have sufficient attitudes towards physics.
\end{abstract}

Key Words: Education, student attitudes, physics, scientific attitudes adoption, increasing time to study physics, career in physics

\begin{abstract}
ABSTRAK
Penelitian ini bertujuan untuk mengetahui sikap siswa terhadap mata pelajaran fisika melalui indikator adopsi sikap ilmiah, ketertarikan dalam memperbanyak waktu belajar fisika dan ketertarikan berkarir dibidang fisika di SMA Ferdy Ferry Putra Kota Jambi. Jenis penelitian yaitu penelitian survei dengan instrumen yang digunakan adalah angket. Subjek penelitian sebanyak 125 siswa. Teknik analisis data kuantitatif menggunakan statistik deskriptif. Hasil analisis yang diperoleh dari indikator adopsi sikap ilmiah dengan kategori baik. Indikator ketertarikan dalam memperbanyak waktu belajar fisika dan ketertarikan berkarir dibidang fisika berkategori cukup. Berdasarkan hasil tersebut, siswa di SMA Ferdy Ferry Putra Kota Jambi memiliki sikap yang cukup terhadap pembelajaran fisika.
\end{abstract}

Kata Kunci: Pendidikan, sikap siswa, fisika, adopsi sikap ilmiah, menambah waktu belajar fisika, berkarir dibidang fisika

\section{PENDAHULUAN}

Pendidikan sangat dibutuhkan agar dapat membimbing peserta didik untuk menggapai cita-citanya melalui wawasan dan ilmu yang telah diberikan dari suatu pendidikan. Melalui pendidikan, siswa bisa menggali potensinya menjadi seseorang yang nantinya berguna bagi nusa dan bangsa. Pendidikan memainkan peran penting dalam meningkatkan kualitas sumber daya manusia (Astalini et al, 2019; Darmaji, Kuriawan \& Suryani, 2018). Dengan adanya pendidikan, manusia dapat merubah tingkah laku dan pengetahuan menjadi lebih baik (Maison, Darmaji, Astalini, Kurniawan \& 
Indrawati, 2019; Taufiqurrahman \& Nida, 2019).

Dalam pendidikan di Indonesia sendiri, terdapat beberapa tingkatan, salah satunya tingkat Sekolah Menengah Atas. Sekolah Menengah Atas merupakan tingkat pendidikan yang wajib ditempuh, sebelum melanjutkan ke tahap pendidikkan selanjutnya ke tingkatan yang lebih tinggi. Pencapaian potensi pendidikan tersebut dapat diperoleh melalui lembaga pendidikan salah satunya Sekolah Menengah Atas (SMA) (Astalini, Kurniawan \& Putri, 2018). Pada tingkatan ini, siswa sudah mulai sedikit demi sedikit mampu mengendalikan dirinya dalam berpikir secara ilmiah. Sebagai pengembangan pola pikir peserta didik maka mata pelajaran yang terkait adalah fisika. Pada kenyataannya, fisika adalah salah satu mata pelajaran yang dianggap berat dan dihindari oleh sebagian peserta didik karena membutuhkan ketekunan, ketelitian dan banyak latihan (Sultan \& Bancong, 2017; Hardiyanti, 2018; Darmaji, Kurniawan, Parasdila \& Irdianti, 2018).

Pelajaran fisika membutuhkan logika yang kuat dan pengetahuan dasar matematika (Guzel, 2004). Sementara menurut Chodijah (2012); Astalini, Kurniawan, Perdana \& Kurniawan (2019) mata pelajaran fisika dipandang penting untuk diajarkan sebagai mata pelajaran karena fisika sebagai wahana untuk menumbuhkan kemampuan berfikir yang berguna untuk memecahkan masalah dalam kehidupan sehari-hari dan membekali peserta didik pengetahuan, pemahaman dan sejumlah kemampuan yang merupakan syarat untuk memasuki jenjang pendidikan yang lebih tinggi. Dalam proses pembelajaran, khususnya dalam pelajaran fisika, sikap peserta didik sangatlah penting.

Sikap merupakan suatu pikiran dan perasaan seseorang untuk mengenal aspek-aspek tertentu di sekitar lingkungannya yang sulit untuk diubah. Sikap adalah pandangan atau perasaan yang disertai kecenderungan untuk bertindak terhadap obyek tertentu (Astalini, Darmaji, Kurniawan \& Destianti, 2019; Taufiqurrahman \& Nida, 2019; Kurniawan, Astalini \& Sari, 2019). Sikap positif siswa terhadap mata pelajaran fisika terlihat ketika siswa antusias saat proses pembelajaran berlangsung, siswa aktif untuk bertanya dan menjawab pertanyaan yang diberikan oleh guru terutama pada saat diskusi kelompok dikelas, sikap positif siswa nya adalah adanya interaksi antara siswa dengan guru pada proses pembelajaran dan begitu pula sebaliknya (Hardiyanti, 2018). Sikap senang siswa terhadap sains dapat ditunjukkan bagaimana siswa bersikap terbuka dan semangat terhadap mata pelajaran sains di dalam atau pun luar kelas (Astalini, Kurniawan, Sari \& Kurniawan, 2019).

Adopsi dari sikap ilmiah siswa berbicara tentang penerapan berperilaku ilmiah dalam mempelajari fisika. Sikap ilmiah memiliki tiga komponen dasar: kepercayaan, perasaan dan tindakan (Mukhopadhyay, 2014). Dari tiga komponen tersebut dapat diterapkan penggunaan cara atau metode ilmiah yang dapat membentuk sikap aktif, memiliki pemikiran yang kritis, terstruktur, mandiri dan logis. Contohnya seperti ketika melakukan suatu kegiatan eksperimen, melalui langkah-langkah percobaan yang terstruktur dan jelas diwajibkan siswa mencari informasi lebih ilmiah. Sehingga, pengetahuan yang didapat akan lebih terkonsep dan terbukti kebenarannya dari hipotesis percobaan yang diteliti siswa.

Ketertarikan dalam memperbanyak waktu belajar fisika dapat diartikan sebagai ungkapan kesukaan siswa dalam mempelajari fisika sehingga mempergunakan waktu luang untuk mempelajari fisika lebih dalam. Sikap siswa terhadap pembelajaran sains mengacu pada perasaan senang atau ketertarikan peserta dalam belajar sains (Esther, 2017; Astalini, Kurniawan \& Sumaryanti, 2018). Siswa akan lebih 
tertarik melakukan eksperimen dirumah, ke perpustakaan, atau membaca buku maupun jurnal tentang fisika yang meningkatkan pengetahuannya. Selain itu, pembelajaran fisika akan terasa senang ketika siswa memiliki karakter yang lebih intensif (Manasia, 2015). Waktu belajar mengacu pada waktu tertentu yang ditetapkan siswa untuk dirinya sendiri untuk belajar untuk memperoleh pengetahuan (Ukpong \& George, 2013). Selain itu juga penambahan waktu belajar ini harus di dukung oleh guru yang mengajar. Menurut Suhendra (2008), usaha guru harus dibantu dengan kegiatan tambahan, usaha tersebut maksudnya untuk memperbaiki mutu pengajaran dan meningkatkan kemampuan anak memahami apa yang dikerjakan.Karena siswa lebih sering meluangkan waktu untuk belajar fisika dengan rutin membuatnya fokus dan memahami konsep. Dengan banyaknya waktu untuk belajar fisika maka akan berdampak baik pada prestasi dan hasil belajar siswa.

Berdasarkan hal tersebut, jika siswa sudah memiliki sikap seperti senang dan tertarik untuk meluangkan waktu terhadap pembelajaran fisika, maka selanjutnya akan menetap dan melanjutkan karirnya dalam bidang Fisika juga. Ketertarikan untuk melanjutkan karir dibidang Fisika tidak lepas dari seberapa besar individu tersebut memiliki keyakinan bahwa berkarir dibidang fisika merupakan salah satu keinginan untuk masa depannya. Dengan kata lain, ketertarikan berkarir dalam bidang fisika dapat meningkatkan sikap siswa terhadap fisika, tetapi tidak semua siswa memilih berkarir dibidang Fisika. Siswa laki-laki secara konsisten memilih jalur karier yang berhubungan dengan sains dan kegiatan ilmiah lebih sering daripada siswa perempuan (Bang \& Baker, 2013). Penerapan kurikulum dan teknologi yang digunakan guru dalam mengajar serta lingkungan siswa yang berubah-ubah menjadi faktor timbulnya perasaan negatif terhadap fisika. Jika siswa diberi terlalu banyak informasi ilmiah, mereka akan memiliki sikap yang lebih negatif. jadi, lingkungan belajar harus dirancang sedemikian rupa sehingga memungkinkan siswa untuk mencapai pengetahuan ilmiah dan mendapatkan sikap yang lebih positif terhadap sains (Hacieminoglu, 2016). Kurangnya pengetahuan dari guru mengenai lemahnya sikap siswa terhadap mata pelajaran fisika memperparah keadaan di mana sikap negatif siswa terhadap fisika akan meningkat.

Tujuan penelitian ini mengetahui sikap siswa terhadap pembelajaran fisika di sekolah menengah atas tepatnya di SMA Ferdy Ferry Putra Kota Jambi. Indikator sikap tersebut meliputi Kesenangan dalam mata pelajaran fisika, Ketertarikan memperbanyak waktu dalam mata pelajaran fisika dan ketertarikan berkarir dalam bidang fisika. Dalam penelitian ini pertanyaan penelitian sebagai berikut :

1. Bagaimana peserta didik ketika mengadopsi sikap ilmiah pada mata pelajaran fisika?

2. Bagaimana sikap peserta didik terhadap ketertarikannya dalam memperbanyak waktu mata pelajaran fisika?

3. Bagaimana sikap peserta didik terhadap ketertarikannya dalam melanjutkan studi dibidang fisika?

Temuan penelitian ini dapat berkontribusi untuk meningkatkan sikap peserta didik terhadap pembelajaran fisika.

\section{METODE PENELITIAN}

Desain penelitian yang digunakan adalah metode penelitian kuantitatif dengan menggunakan metode survei. Populasi pada penelitian ini yaitu 536 siswa dari SMA Ferdy Ferry Putra Kota Jambi. Sampel yang diambil dalam penelitian ini adalah 125 siswa dari SMA Ferdy Ferry Putra Kota Jambi. Teknik pengambilan sampel yang digunakan dalam penelitian ini adalah purposive sampling. Purposive sampling yaitu sampel yang dilakukan 
dengan cara mengambil subyek bukan didasarkan atas strata, random atau daerah tetapi didasarkan atas adanya tujuan tertentu (Heridiansyah, 2012). Instrumen yang digunakan yaitu kuesioner yang diadopsi dari penelitian Rio Darmawangsa (2018). Fokus dari penelitian ini adalah pada tiga dimensi sikap yaitu adopsi sikap ilmiah, ketertarikan memperbanyak waktu fisika dan ketertarikan berkarir dibidang fisika. Analisis data yang digunakan adalah analisis deskriptif. Suatu gambaran atau penyajian data dalam jumlah besar yang mencakup mean, modus, median, maksimum, minimum, dan standar deviasi merupakan statistik deskriptif (Cohen, 2007). Data dianalisis menggunakan program SPSS 22 untuk mendapatkan persentase, frekuensi, rata-rata data.

\section{HASIL DAN PEMBAHASAN}

Adapun hasil dari 3 indikator yang digunakan adalah sebagai berikut:

\section{Adopsi dari sikap ilmiah}

Adopsi dari sikap ilmiah adalah siswa yang menempatkan dirinya sebagai ilmuwan serta bersikap ilmiah dengan segala macam kehidupan dan kebiasaannya. Pada adopsi dari sikap ilmiah siswa terhadap fisika di SMA Ferdy Ferry Putra Kota Jambi dapat kita lihat hasilnya dari angket yang telah disebarkan, dengan hasil seperti tabel 1.

Tabel 1. Adopsi dari Sikap Ilmiah Siswa di SMA Ferdy Ferry Putra Kota Jambi

\begin{tabular}{clcccccc}
\hline \multicolumn{1}{c}{ Knterval } & \multicolumn{1}{c}{ Sikap } & Total & Mean & Median & Min & Max & \% \\
\hline $7.0-12.6$ & $\begin{array}{l}\text { Sangat Tidak } \\
\text { Baik }\end{array}$ & 0 & & & & 0 \\
$12.7-18.2$ & Tidak Baik & 1 & \multirow{2}{*}{26.45} & 26 & \multirow{2}{*}{17} & 35 & 0.8 \\
$18.3-23.8$ & Cukup & 27 & & & & 21.6 \\
$23.9-29.4$ & Baik & 69 & & & & 55.2 \\
$29.5-35.0$ & Sangat Baik & 28 & & & & 22.4 \\
\hline TOTAL & & 125 &
\end{tabular}

Pada Tabel 1 untuk adopsi dari sikap ilmiah siswa di SMA Ferdy Ferry Putra Kota Jambi memiliki persentase paling dominan yaitu kategori baik sebesar 55.2\% (69 dari 125 siswa). Dalam hal ini, siswa dapat menempatkan dirinya seperti halnya ilmuwan serta bersikap ilmiah dengan segala macam kehidupan dan kebiasaannya dalam mengerjakan tugas fisika dikelas. Sikap positif inilah yang dapat dimiliki oleh seorang ilmuan (Nasrodin, 2013; Astalini, Kurniawan \& Anggraini, 2019; Astalini, et al, 2019).

Kebiasaan siswa yang penasaran dengan hal-hal baru akan menimbulkan pertanyaan di pikiran siswa dan membuat mereka mencari tau tentang hal tersebut (Erdogan, 2017). Bentuk Apresiasi dan dukungan untuk penyelidikan ilmiah dari peserta didik menunjukkan bahwa mereka menghargai cara ilmiah mengumpulkan bukti, berpikir kreatif, berpikir rasional, menanggapi secara kritis, dan berkomunikasi, kesimpulan, karena mereka menghadapi situasi kehidupan yang berkaitan dengan sains (Bybee dkk, 2009; Astalini, Kurniawan, Perdana \& Kurniasari, 2018).

Siswa memiliki rasa ingin tahu yang tinggi serta menerima pendapat dari orang lain. Siswa yang memiliki sikap ilmiah yang tinggi akan memiliki keinginan yang juga tinggi untuk menemukan dan menciptakan hal baru, terbuka, bekerjasama dalam tim, dan bertanggungjawab dengan tugas (Anisa dkk, 2013). Kebiasaan siswa akan hal-hal yang baru akan menimbulkan banyak pertanyaan dan sikap kritis siswa serta membuat mereka mencari tau sendiri tentang hal tersebut. Sikap sains akan mendorong kemauan siswa untuk mengajukan pertanyaan dalam pemikiran siswa dan meningkatkan semangat untuk menemukan jawaban permasalahan (Rosdianto, 2017). 
Tarbiyah: Jurnal Ilmiah Kependidikan

Vol. 8 No. 2 Juli - Desember 2019 (91-100)

Ketertarikan memperbanyak waktu belajar fisika

kita lihat hasilnya dari angket yang telah

Ketertarikan memperbanyak waktu belajar fisika merupakan rasa ingin tahu dan penasaran akan materi-materi dari mata pelajaran fisika. Pada Ketertarikan memperbanyak waktu bealajar fisika di SMA Ferdy Ferry Putra Kota Jambi dapat

Tabel 2. Ketertarikan memperbanyak waktu belajar di SMA Ferdy Ferry Putra Kota Jambi

\begin{tabular}{|c|c|c|c|c|c|c|c|}
\hline \multicolumn{3}{|c|}{ Karakteristik } & \multirow{2}{*}{ Mean } & \multirow{2}{*}{ Median } & \multirow{2}{*}{ Min } & \multirow{2}{*}{$\operatorname{Max}$} & \multirow{2}{*}{$\%$} \\
\hline Interval & Sikap & Total & & & & & \\
\hline $8.0-14.4$ & $\begin{array}{l}\text { Sangat Tidak } \\
\text { Baik }\end{array}$ & 1 & & & & & 0.8 \\
\hline $14.5-20.8$ & Tidak Baik & 11 & 2468 & 24 & 13 & 37 & 8.8 \\
\hline $20.9-27.2$ & Cukup & 90 & 24.08 & 24 & 15 & I & 72.0 \\
\hline $27.3-33.6$ & Baik & 21 & & & & & 16.8 \\
\hline $33.7-40.0$ & Sangat Baik & 2 & & & & & 1.6 \\
\hline TOTAL & & 125 & & & & & \\
\hline
\end{tabular}

Pada Tabel 2 dapat dideskripsikan ketertarikan memperbanyak waktu belajar di SMA Ferdy Ferry Putra Kota Jambi yang paling dominan yaitu kategori cukup dengan presentase sebesar $72 \%$ (90 dari 125 siswa) dengan skor maksimal dari keseluruhan pernyataan di indikator 2 adalah 37. Hal ini menunjukkan bahwa siswa di SMA Ferdy Ferry Putra Kota Jambi tidak memiliki atau meluangkan waktu yang banyak untuk mepelajari fisika. Sebanyak $17.6 \%$ siswa (23 dari 125) berkategori baik dan $9.6 \%$ siswa (12 dari 125) berkategori tidak baik. Siswa yang memiliki sikap ilmiah yang tinggi akan memiliki keingintahuan dan keinginan yang juga tinggi untuk menemukan dan menciptakan hal baru, terbuka, bekerjasama dalam tim, dan bertanggungjawab dengan tugas (Anisa dkk, 2013; Riwahyudin, 2015; Kurniawan, Astalini, Susanti \& Maison, 2018).

Kebiasaan siswa yang penasaran dengan hal-hal baru akan menimbulkan pertanyaan di pikiran siswa dan membuat mereka mencari tau tentang hal tersebut. Hal tersebut menunjukkan adanya interaksi signifikan antara sikap, kepercayaan dan kebiasaan (Erdogan, 2017; Suryandari, 2018). Sikap sains akan mendorong kemauan siswa untuk mengajukan pertanyaan dalam pemikiran siswa dan meningkatkan semangat untuk menemukan jawaban permasalahan (Rosdianto, 2017).

Siswa yang dari awal tidak menyukai Fisika akan kurang memperhatikan penjelasan guru atau bahkan tidak mendengarkan penjelasan guru (Lebdiana, Sulhadi, \& Hindarto, 2015; Suryandari, Kadarisman \& Sudomo, 2018; Asrial, Syahrial, Kurniawan \& Amalina, 2019). Jadi, materi dasar dari mata pelajaran fisika itu memang harus kita ketahui terlebih dahulu, ibaratkan kita harus memiliki pondasinya terlebih dahulu. Jika dasarnya saja kita tidak tahu, maka untuk materi selanjutnyapun akan sulit untuk dipahami. Sehingga, kita tidak ingin meluangkan waktu untuk belajar fisika.

Menurut Abbas \& Hidayat (2018) kesulitan peserta didik bisa ditemui ketika belajar Fisika dalam kelas yang sebagian peserta didik masih ada yang selalu tertinggal dalam mengerjakan tugas dengan waktu yang ditentukan. Selain itu, sekolah terkadang tidak menyediakan fasilitas yang menunjang proses pembelajaran Fisika. Karena dengan adanya pemanfaatan media atau fasilitas lainnya akan membantu siswa mengurangi ketidaksukaan mereka terhadap Fisika. Belajar individu dirumah adalah salah satu proses belajar yang optimal bila dilakukan 
dengan baik dan sungguh-sungguh supaya tercapainya hasil yang memuaskan (Nursina, 2017; Asrial, Syahrial, Kurniawan \& Maretika, 2018; Asrial et al, 2019; Darmaji, Kurniawan, Parasdila \& Irdianti, 2018).

\section{Ketertarikan berkarir dibidang Fisika}

Ketertarikan berkarir dibidang fisika merupakan suatu keinginan untuk melanjutkan studi dibidang fisika. Hasil angket yang telah disebarkan dan diolah tentang Ketertarikan berkarir dibidang fisika di SMA Ferdy Ferry Putra Kota Jambi dapat dilihat pada tabel 4.

Tabel 3. Ketertarikan berkarir dibidang Fisika di SMA Ferdy Ferry Putra Kota Jambi

\begin{tabular}{|c|c|c|c|c|c|c|c|}
\hline \multicolumn{3}{|c|}{ Karakteristik } & \multirow{2}{*}{ Mean } & \multirow{2}{*}{ Median } & \multirow{2}{*}{ Min } & \multirow{2}{*}{ Max } & \multirow{2}{*}{$\%$} \\
\hline Interval & Sikap & Total & & & & & \\
\hline $10.0-18.0$ & $\begin{array}{l}\text { Sangat Tidak } \\
\text { Baik }\end{array}$ & 0 & & & & & 0.0 \\
\hline $18.1-26.0$ & Tidak Baik & 29 & 21 & 20 & م & 20 & 23.2 \\
\hline $26.1-34.0$ & Cukup & 85 & 29.21 & 30 & 20 & 38 & 68.0 \\
\hline $34.1-42.0$ & Baik & 11 & & & & & 8.8 \\
\hline $42.1-50.0$ & Sangat Baik & 0 & & & & & 0.0 \\
\hline
\end{tabular}

Pada Tabel 3 untuk ketertarikan berkarir dibidang fisika di SMA Ferdy Ferry Putra Kota Jambi memiliki persentase paling dominan yaitu kategori cukup dengan persentase $68 \%$ (85 dari 125 siswa). Hal ini menunjukkan bahwa masih banyak keraguan dari siswa di SMA Ferdy Ferry Putra Kota Jambi melanjutkan karirnya dibidang fisika. Sebanyak $8.8 \%$ siswa (11 dari 125) berkategori baik dan terdapat $23.2 \%$ siswa (29 dari 125) berkategori tidak baik hal ini menunjukkan siswa tidak tertarik untuk melanjutkan studinya dibidang fisika. Peserta didik yang bisa menghargai peran fisika dalam kehidupan sehari-hari, hanyalah peserta didik yang berprestasi baik di fisika SMA, berbakat dalam sains, dan sangat baik dalam matematika (Guido, 2013).

Sikap peserta didik yang suka bertanya setelah berusaha mencari solusi atau jawaban tersebut menunjukkan bahwa rasa keingintahuan serta ketertarikan peserta didik sangat besar terhadap penyelidikan yang dilakukannya. Berdasarkan hal tersebut, jika siswa sudah memiliki sikap seperti seorang ilmuan serta bersikap ilmiah terhadap pembelajaran fisika, maka selanjutnya siswa akan menetap dan melanjutkan karirnya dalam bidang fisika juga (Hardiyanti dkk, 2018; Juan, 2016). Minat sangat mempengaruhi pencapaian karir dan kehidupan pribadi siswa (Bybee dkk, 2009; Kurniawan, Astalini \& Anggraini, 2018). Namun, siswa juga harus mengetahui minatnya terhadap pelajaran itu sendiri karena minat sangat mempengaruhi pencapaian karir dan kehidupan pribadi siswa (İzzet \& Arslan, 2015; Ediansyah et al., 2019; Putra \& Wiza, 2019). Dalam hal ini, sebagian besar siswa di SMA Ferdy Ferry Putra Kota Jambi tidak semua mau melanjutkan studinya dibidang fisika.

\section{PENUTUP}

Berdasarkan hasil analisis yang didapatkan, sikap siswa dalam tiap indikator di SMA Ferdy Ferry Putra Kota Jambi memiliki kategori yang hampir sama, hal ini dapat terlihat terutama dari guru pengampu bidang studi yang ada di sekolah, bagaimana cara guru dalam menanamkan konsep kepada siswa agar tidak memiliki anggapan bahwa fisika adalah pelajaran yang sulit. Selain itu siswa yang memiliki sikap ilmiah dalam pembelajaran fisika belum tentu tertarik untuk lanjut berkarir dibidang fisika. Dari data juga tampak bahwa siswa juga tidak terlalu berkeinginan untuk berkarir dibidang fisika. Seperti menjadi ilmuwan, bekerja di laboratorium, menjadi guru 
maupun dosen fisika, dan lain sebagainya. Selain itu, anggapan mereka bahwa pada jenjang pendidikan yang lebih tinggi maka pelajaran fisika makin sulit dan untuk mencapai cita-cita berkarir di bidang fisika memerlukan waktu yang cukup layak.

\section{DAFTAR PUSTAKA}

Abbas, A., \& Hidayat, M. Y. (2018). Faktor-faktor kesulitan belajar fisika pada peserta didik kelas IPA sekolah menengah atas. Jurnal Pendidikan Fisika. 6(1), 45-50.

Agunbiade, E., Ngcoza, K., Jawahar, K., \& Sewry, J. (2017). An exploratory study of the relationship between learners' attitudes towards learning science and characteristics of an afterschool science club. African Journal of Research in Mathematics, Science and Technology Education, 21(3), 271281.

Anisa, D. N., Masykuri, M., \& Yamtinah, S. (2013). Pengaruh model pembelajaran poe (predict, observe, and explanation) dan sikap ilmiah terhadap prestasi belajar siswa pada materi asam, basa dan garam kelas VII semester 1 SMP N 1 Jaten tahun pelajaran 2012/2013. Jurnal Pendidikan Kimia (JPK), 2(2), 1623.

Asrial, A., Syahrial, S., Kurniawan, D, A., Chan, F., Nugoroho, P., Pratama, R, A., \& Septiasari, R. (2019). Identification: the effect of mathematical competence on pedagogic competency of prospective teacher, Humanities \& Social Sciences Reviews (HSSR), 7(4), 85-92.

Asrial, A., Syahrial, S., Kurniawan, D. A., \& Amalina, N. (2019). Analisis hubungan kompetensi bahasa indonesia terhadap kompetensi pedagogik mahasiswa pendidikan guru sekolah dasar. Premiere Educandum: Jurnal Pendidikan Dasar dan Pembelajaran, 9(1), 1-8.

Astalini A., Darmaji, D., Pathoni, H., Kurniawan, W., Jufrida, J., Kurniawan, D. A., \& Perdana, R. (2019). Motivation and attitude of students on physics subject in the middle school in indonesia. International Education Studies (IES) Journal, 12(9), 15-26.

Astalini A., Kurniawan, D. A., Darmaji, D., Sholihah, L. R., \& Perdana, R. (2019). Characteristics of students' attitude to physics in muaro jambi high school. Humanities \& Social Sciences Reviews (HSSR), 7(2), 9199.

Astalini, A., Darmaji D., Kurniawan, D. A., \& Destianti, A. (2019). Description of the dimensions attitudes towards science in junior high school at muaro jambi. International Journal of Sciences: Basic and Applied Research (IJSBAR), 47(1), 1-11.

Astalini, A., Kurniawan, D, A., \& Anggraini, L. (2019). Correlation between confidence with attitude toward science in secondary school in Indonesia. Beder Scientific Journal of Education Sciences ( BJES), 20(1), 30-45.

Astalini, A., Kurniawan, D, A., Kurniawan, N., \& Anggraini, L. (2019). Evaluation of student's attitude toward science in indonesia. Open Journal for Educational Research (OJER), 3(1), 1-12.

Astalini, A., Kurniawan, D, A., Perdana, R., \& Pathoni, H. (2019). Identifikasi sikap peserta didik terhadap mata pelajaran fisika di sekolah menengah atas negeri 5 kota jambi, UPEJ Unnes Physics Education Journal, 8(1), 34-43. 
Astalini, A., Kurniawan, D. A., \& Putri, A, D. (2019). Identifikasi sikap implikasi sosial dari IPA, ketertarikan menambah waktu belajar IPA, dan ketertarikan berkarir dibidang IPA siswa SMP se-kabupaten muaro jambi. Jurnal Tarbiyah Jurnal Ilmiah Kependidikan, 7(2), 93-108.

Astalini, A., Kurniawan, D. A., \& Sumaryanti, S. (2018). Sikap siswa terhadap pelajaran fisika di sman kabupaten Batanghari. JIPF (Jurnal Ilmu Pendidikan Fisika), 3(2), 5964.

Astalini, A., Kurniawan, D. A., Sari, D. K., \& Kurniawan, W. (2019). Description of scientific normality, attitudes of investigation and interested career on physics in senior high school. JIPF (Jurnal Ilmu Pendidikan Fisika), 4(2), 5663.

Bang, E., \& Baker, D, R. (2013). Gender differences in Korean high school students' science achievements and attitudes towards science in three different school settings. Online Submission, 3(2), 27-42.

Bybee, R., McCrae, B., \& Laurie, R. (2009). PISA 2006: An assessment of scientific literacy. Journal of Research in Science Teaching: The Official Journal of the National Association for Research in Science Teaching, 46(8), 865-883.

Chodijah, S., Fauzi, A., \& Ratnawulan, R. (2012). Pengembangan perangkat pembelajaran fisika menggunakan model guided inquiryyang dilengkapi penilaian portofolio pada materi gerak melingkar. Jurnal Penelitian Pembelajaran Fisika, 1(1), 1-19.
Cohen, L., Manion, L., \& Marrison, K. (2007). Research Methods in Education. New York: Routledge.

Darmaji, D., Astalini, A., Kurniawan, D. A., Perdana, R., \& Putra, D. S. (2019). A study relationship attitude toward physics, motivation, and character discipline students senior high school, in Indonesia. International Journal of Learning and Teaching, 11(3), 99-109.

Darmaji, D., Kurniawan, D. A., \& Suryani, A. (2019). Effectiveness of basic physics ii practicum guidelines based on science process skills, JIPF (Jurnal Ilmu Pendidikan Fisika), 4(1), 1-7.

Darmaji, D., Kurniawan, D. A., Parasdila, H., \& Irdianti, I. (2018). Deskripsi keterampilan proses sains mahasiswa pada materi termodinamika. Berkala Ilmiah Pendidikan Fisika, 6(3), 345-353.

Darmawangsa, R. (2018). Pengembangan instrumen sikap siswa sekolah menengah atas terhadap mata pelajaran fisika. Jurnal Pendidikan Fisika-Journal of Physics Education, 6(1), 107-114.

Ediansyah, E., Kurniawan, D, A., Salamah, S., \& Perdana, R. (2019). Investigation of problem based learning: process of understanding the concepts and independence learning on research statistics subject, Humanities \& Social Sciences Reviews (HSSR), 7(5), 111.

Erdogan, S. C. (2017). Science teaching attitudes and scientific attitudes of pre-service teachers of gifted students. Journal of Education and Practice, 8(6), 164-170.

Guzel, H. (2004). The relationship between students' success in physics lessons and their attitude towards 
Tarbiyah: Jurnal Ilmiah Kependidikan

Vol. 8 No. 2 Juli - Desember 2019 (91-100)

mathematics. Turkish Science Education, 1(1), 28-29.

Hacieminoglu, E. (2016). Elementary school students' attitude toward science and related variables. International Journal of Environmental and Science Education, 11(2), 35-52.

Hardiyanti, K., Astalini, A., \& Kurniawan, D. A. (2018). Sikap siswa terhadap mata pelajaran fisika di SMA Negeri 5 Muaro Jambi. EduFisika, 3(2), 112.

Heridiansyah, J. (2012). Pengaruh advertising terhadap pembentukan brand awareness serta dampaknya pada keputusan pembelian produk kecap pedas ABC (studi kasus pada konsumen pengguna kecap pedas abc di kota semarang), Jurnal STIE Semarang, 4(2), 53-73.

İzzet Kurbanoğlu, N., \& Arslan, S. (2015). High school students' educational and career interest (sciencetechnology-mathematics) and career adaptabilities. Australian Journal of Career Development, 24(3), 166172

Kurniawan, D. A., \& Susanti, A. (2018). Attitudes of college students on the subject of mathematical physics III in physics education program of jambi university. The Educational Review, USA, 2(11), 505-513.

Kurniawan, D. A., Astalini, A., \& Sari, D, K. (2019). An evaluation analysis of students' attitude towards physics learning at senior high school. Jurnal Penelitian dan Evaluasi Pendidikan, 23(1), 26-35.

Kurniawan, D. A., Perdana, R., \& Kurniasari, D. (2018). Identification of student attitudes toward physics learning at batanghari district high school. The Educational Review, USA, 2(9), 475-484.
Kurniawan, D. A., Perdana, R., \& Kurniawan, W. (2019). Identification attitudes of learners on physics subjects. Journal of Educational Science and Technology (EST), 5(1), 56-63.

Lebdiana, R., Sulhadi, \& Hindarto, N. (2015). Pengembangan prangkat pembelajaranmateri suhu dan kalor berbasis POE (Predict-ObserveExplain) untuk meremediasi miskonsepsi siswa. Unnes physics Education Journal. 4(2).

Maison, M., Darmaji, D., Astalini, A., Kurniawan, D, A., \& Indrawati, P, S. (2019). Science process skills and motivation, Humanities \& Social Sciences Reviews (HSSR), 7(5), 4856.

Manasia, L. (2015). Enjoyment of learning in upper secondary education. An Exploratory Research. Procedia-Social And Behavioral Sciences, 180(2015), 639-646.

Maretika, L. D., \& Kurniawan, D. A. (2018). Analisis kompetensi pedagogik dan kompetensi IPA terhadap calon guru sekolah dasar PGSD FKIP universitas jambi. Jurnal DIDIKA: Wahana Ilmiah Pendidikan Dasar, 4(2), 4149.

Mukhopadhyay, R. (2014). Scientific attitude-some psychometric considerations. IOSR Journal Of Humanities And Social Science (IOSR-JHSS) OSR-JHSS, 19(1), 98100.

Nasrodin, N., Hindarto, N., Supeni, S. E. (2013). Analisis kebiasaan belajar ilmiah mahasiswa fisika pada pembelajaran mata kuliah praktikum fisika dasar. Unnes Physics Educational Journal. 2(1), 84-91. 
Nursina,. (2017). Penggunaan smartphone dalam mengembangkan pola belajar siswa SMA Negeri 1 Kulisusu Utara Kabupaten Buton Utara. Journal Ilmu Komunikasi UHO. 2(1).

Putra, D. S., \& Wiza, O, H. (2019). Analisis sikap siswa terhadap mata pelajaran fisika di SMA ferdy ferry putra kota jambi, UPEJ Unnes Physics Education Journal, 8(3), 299-311.

Riwahyudin, A. (2015). Sikap siswa dan minat belajar siswa terhadap hasil belajar IPA siswa kelas V sekolah dasar di kabupaten lamandau. Jurnal Pendidikan Dasar. 6(1). 11-23.

Rosdianto, H. (2017). Penentuan percepatan gravitasi pada percobaan gerak jatuh bebas dengan memanfaatkan rangkaian relai. Spektra: Jurnal Fisika dan Aplikasinya, 2(2), 107-112.

Suhedra. (2008). Pengaruh penambahan waktu belajar agama islam terhadap prestasi belajar siswa pada mata pelajaran PAI (penelitian pada siswa kelas II SMPN 3 cikajang garut). Jurnal Pendidikan Universitas Garut, 2(1), 26-36.

Sultan, A. D., \& Bancong, H. (2017). Pengaruh pendekatan multiple intelligences melalui model pembelajaran langsung terhadap sikap dan hasil belajar fisika peserta didik kelas XI IPA SMA Negeri 11 makassar. Jurnal Pendidikan Fisika Universitas Muhammadiyah Makassar, 5(1), 51-60.

Suryandari, S., Kadarisman, N., \& Sudomo, J. (2018). Perbedaan keterampilan berpikir kritis siswa yang berbantuan media audio visual dan lks cetak sebagai panduan percobaan pada metode eksperimen dengan pendekatan verifikasi kelas XI SMA Negeri 1 Sewon. Jurnal Tarbiyah: Jurnal Ilmiah Kependidikan, 7(1), 37-40.

Syahrial, S., Asrial, A., Kurniawan, D, A., Chan, F., Hariandi, A., Pratama, R, A., Nugroho, P., \& Septiasari, R. (2019). Analysis of the impact of etnocontructivism in social affairs on pedagogic competencies of basic school teachers in indonesia, International Journal of Evaluation and Research in Education (IJERE), 8(3), 85-92.

Taufiqurrahman, T., \& Nida, N, H. (2019). Pendidikan karakter perilaku sosial anak usia sekolah dasar dalam keluarga di kota banjarmasin. Jurnal Tarbiyah: Jurnal Ilmiah Kependidikan, 8(1), 75-90.

Ukpong, D. E., \& George, I. N. (2013). Length of study-time behaviour and academic achievement of social studies education students in the university of uyo. International Education Studies, 6(3), 172-178. 